\title{
Feasibility Analysis of Business; Case Study in Indonesia Minimarket
}

\author{
Ali Sandy Mulya, M.Si, FranciscaHermawan, Benedicta Prabawanti Evienia
}

\begin{abstract}
This study discusses the feasibility analysis of the business of selling online and offline on minimarket is already in line and see the results of the analysis SWOT on each of the elements business used in the online sales. The data used in this study are primary data. Retrieval of data used by way of a market test by distributing questionnaires to 55 respondents was selected using non-probability sampling with technique. purposive sampling results of the validation test $t$ count> $t$ table with the 5\% significance show valid questionnaires and retail business means the reliable mini market demand by prospective customers. The results of the financial feasibility of identification, including $N P V>0, R p$ 444806520 means the mini-market retail business feasible. Payback period is obtained in the ninth. Results 2015-2016 Internet user data on demographic segment increased significantly also aspects of technology and internet users growing rapidly in the modern era. The result of identification of analysis strengths and threats states that the power of business that sell staples, the location within the housing and provided services inter whereas its business challenges the traditional market, wet market and supplier delays delivering goods.
\end{abstract}

\section{Introduction}

Since 5 years ago, minimarket growth in Indonesia is very large, this is due to the impact of economic growth in Indonesia as well as the development of equitable development undertaken by the government of President JokoWidodo [1-5]. The existence of Indonesia's economic growth significantly impacts the creation of welfare for the whole society. The Central Bureau of Statistics released economic growth figures Indonesia I \& II quarter of 2017 amounted to $5.01 \%$ lower than in 2016 , namely $5.18 \%$. The increase in welfare that occurs almost anywhere in Indonesia raises the amount of consumption of Indonesian society is quite large, visible from the last 10 years the number of retail sales is in a position beyond the value of GDP in spite of GDP decline [6-10].

Indonesia's large population, accompanied by the development of internet usage on mobile devices, desktop, and tablet in Indonesia has been increasing in recent years [11-14]. Growth in the number of Internet users is followed by a growing number of users of social media services [1216]. Based on the data and the background of the

Revised Manuscript Received on July 05, 2019.

Dr. Ali Sandy Mulya,

UniversitasBudi Luhur, alisandy@outlook.com development of internet users is increasing, the researcher is interested in conducting research on

the implementation of the sales strategy of using online media to

perform analysis using the concept analysis feasibility with a view financial aspects, market, marketing, technology and business opportunities and challenges observed from $\mathrm{OK}$ Mart [17-21].

\section{Retail Industry In Indonesia}

At first the retail industry in Indonesia are shaped like traditional wet markets and traditional markets, but development of the times and the changes in consumption behavior of citizens are demanding retailers to create a shopping place that is able to meet local needs for comfort and convenience in shopping so that opened the first modern outlets in Jakarta with format Sarinah department store with a name in the 1960s. In the following year came the modern retail outlets more modern both inside and outside the country seems like Hero, Sun, Metro, Sogo, Indogrosir, Indomaret, Alfamart, and others. The retail industry in Indonesia showed a good performance, especially traditional retail, and modern retail.

The growth of modern retail minimarket very large because Indonesia is a fertile ground for the establishment of a retail business. Retail growth factors are a large number of population, the growth of the good performance, the growth of equitable development, the growing number of middleclass population and the needs of the community to meet basic needs. This is supported by research Mulya, Ali Sandy (2017) which stated investment opportunities has a significant influence on sustainable enterprise, and valueadded companies Significantly Affect indirectly on sustainable enterprise through a set of investment opportunities in which to develop business retail businesses need a good performance,

According to Director General of Domestic Trade Ministry of Commerce, Sri Agustina which the Business Information Focus (2016) states that the retail outlets in Indonesia continue to experience positive growth in the last 10 years with the growth of modern retail format minimarket $400 \%$.

Published By:

Blue Eyes Intelligence Engineering 


\begin{tabular}{|c|c|c|c|c|c|c|c|c|c|c|}
\hline $\begin{array}{l}\text { Ta } \\
\text { hu } \\
\text { n }\end{array}$ & $\begin{array}{l}\text { Super } \\
\text { mark } \\
\text { et }\end{array}$ & $\begin{array}{l}\text { Dept } \\
\text {.Stor } \\
\mathrm{e}\end{array}$ & $\begin{array}{l}\text { Mini } \\
\text { mark } \\
\text { et }\end{array}$ & $\begin{array}{l}\text { Hype } \\
\text { rmark } \\
\text { et }\end{array}$ & $\begin{array}{l}\text { To } \\
\text { tal }\end{array}$ & & & & & \\
\hline & $\begin{array}{l}\text { outlet } \\
\text { s }\end{array}$ & $\begin{array}{l}\text { Add } \\
\text { ed }\end{array}$ & $\begin{array}{l}\text { Outl } \\
\text { ets }\end{array}$ & $\begin{array}{l}\text { Adde } \\
\mathrm{d}\end{array}$ & $\begin{array}{l}\text { ou } \\
\text { tle } \\
\text { ts }\end{array}$ & $\begin{array}{l}\text { Ad } \\
\text { de } \\
\text { d }\end{array}$ & $\begin{array}{l}\text { ou } \\
\text { tle } \\
\text { ts }\end{array}$ & $\begin{array}{l}\text { Ad } \\
\text { de } \\
d\end{array}$ & $\begin{array}{l}\text { ou } \\
\text { tle } \\
\text { ts }\end{array}$ & $\begin{array}{l}\text { Ad } \\
\text { de } \\
d\end{array}$ \\
\hline $\begin{array}{l}20 \\
10\end{array}$ & 1.652 & & 724 & & $\begin{array}{l}12 . \\
75 \\
6\end{array}$ & & $\begin{array}{l}19 \\
9\end{array}$ & & $\begin{array}{l}15 . \\
33 \\
1\end{array}$ & \\
\hline $\begin{array}{l}20 \\
11\end{array}$ & 1.727 & 75 & 759 & 35 & $\begin{array}{l}15 . \\
22 \\
6\end{array}$ & $\begin{array}{l}2 . \\
47 \\
0\end{array}$ & $\begin{array}{l}22 \\
0\end{array}$ & 21 & $\begin{array}{l}17 . \\
93 \\
2\end{array}$ & $\begin{array}{l}. \\
60 \\
1\end{array}$ \\
\hline $\begin{array}{l}20 \\
12\end{array}$ & 1.847 & 120 & 799 & 40 & $\begin{array}{l}18 . \\
26 \\
3\end{array}$ & $\begin{array}{l}3 . \\
03 \\
7\end{array}$ & $\begin{array}{l}25 \\
4\end{array}$ & 34 & $\begin{array}{l}21 . \\
16 \\
3\end{array}$ & $\begin{array}{l}3 . \\
23 \\
1\end{array}$ \\
\hline $\begin{array}{l}20 \\
13\end{array}$ & 1.982 & 135 & 844 & 45 & $\begin{array}{l}21 . \\
73 \\
3\end{array}$ & $\begin{array}{l}3 . \\
47 \\
0\end{array}$ & $\begin{array}{l}28 \\
3\end{array}$ & 29 & $\begin{array}{l}24 . \\
84 \\
2\end{array}$ & $\begin{array}{l}3 . \\
67 \\
9\end{array}$ \\
\hline $\begin{array}{l}20 \\
14\end{array}$ & 2.107 & 125 & 884 & 40 & $\begin{array}{l}25 . \\
13 \\
0\end{array}$ & $\begin{array}{l}3 . \\
39 \\
7\end{array}$ & $\begin{array}{l}30 \\
2\end{array}$ & 19 & $\begin{array}{l}28 . \\
42 \\
3\end{array}$ & $\begin{array}{l}3 . \\
58 \\
1\end{array}$ \\
\hline $\begin{array}{l}20 \\
15\end{array}$ & 2.152 & 45 & 904 & 20 & $\begin{array}{l}26 . \\
00 \\
5\end{array}$ & $\begin{array}{l}87 \\
5\end{array}$ & $\begin{array}{l}31 \\
2\end{array}$ & 10 & $\begin{array}{l}29 . \\
37 \\
3\end{array}$ & $\begin{array}{l}95 \\
0\end{array}$ \\
\hline
\end{tabular}

Table 1.Total Retail Modern Developments in Indonesia from 2010 to 2015

The year 2010 to 2015 the number of modern retail on the entire format has increased the number of outlets is increasing supermarket of 2010/2015 amounted to $130 \%$, the increase in department store of 2010/2015: $125 \%$, increase in hypermarket $2010 / 2015$ year $157 \%$ and the greatest increase seen from the mini format that is $204 \%$.

\section{Business Strategies}

The research was conducted at the minimarket growing in West Java. Minimarket selected as the research object is OK Mart.

Ok Mart is a minimarket withformat nonfranchise that has potential competitors, namely the franchise named Alfamart minimarket and Indomaret. The marketing strategy minimarket this franchise that sale shopping every weekend at a low price so as to create consumer interest to shop at the minimarket franchise., It is appropriate to research Mulya, Ali Sandy (2017) claimed the generic strategy affect the company's sustainability and business strategy needs to be done for the development of firms proxied by Minimarket.

To cope with the various threats from the presence of minimarket franchise, OK Mart chose to use some strategies to be superior to its competitors, such as a) Providing home delivery to consumers in the residential area where Ok Mart is, without providing additional service fee, b). Setting a lower price than its competitors for goods of basic needs, c). Sale shopping is not only during weekend alone but on a normal day for certain products, for example, buy 1 get 1 free, or promo purchase with the purchase, and promo discount for payment by debit card or credit card particular bank, d) provide purchase services via telephone, SMS, or other digital media, which make it easy for consumers to shop at OK Mart.

\section{Feasibility of Business}

In assessing the feasibility of the business concept Mart $\mathrm{Ok}$, researchers focused primarily on the financial aspects, market and marketing aspects as well as aspects of the technology. Some aspects of the feasibility study have relevance to one another, such as financial aspects, have a relation to aspects of the market and sales because it includes the value of sales projections. Sales projections will be associated with the projection of incoming cash, while the projected costs would be associated with the projected cash out. Projections of cash inflows minus outflows flow projections will generate net cash flows. The net flow is used to perform a feasibility analysis on the financial the aspects

The marketing aspect, researchers use market theory (Pheng, 1990) which states that the market in society has an important role as a center of economic activity and cultural center. As the center of economic activity, a market is a meeting place for producers and consumers. Through the market, people can get their production needs such as capital, equipment, and energy. Based on the above market theory, minimart OK Mart in the main activity is providing daily necessities through diverse and quality products that can meet the needs of consumers. Besides main activities carried out by minimarket OK Mart is providing daily needs through a diverse and high-quality product to meet consumer needs. Besides the main activity, OK Mart is to conduct surveillance and control of resources OK Mart so that all operations run properly and in accordance with the procedure OK Mart operation. While the main power sourceto the success of OK Mart is the source of sufficient capital for business development, and the presence of qualified human resources to ensure the smooth operation of the store, the trademark of every product sold in Ok Mart equipped with activities and selling goods through retail software to facilitate activities sales and purchases of daily necessities products. Furthermore, the process of providing products daily necessities, OK Mart minimarket in cooperation with suppliers, among others; Gas Pelita Nusantara, five Pandavas, Indomarco, Tirta investment,

Surya AnugerahSentosa.Management minimarket create Customer Relationship the relationship to consumers by doing; Telemarketing, this service is provided to its customers at the beginning of the month as a way to reach the hearts of consumers in terms of satisfying the needs of everyday life, then the email is a forum for the delivery of criticism and suggestions from consumers for Management OK Mart. Via email expected any form of complaints can be resolved quickly by providing the best solutions from $\mathrm{OK}$ Mart management to consumers. Furthermore, management does self-service, which means that the management was OK Mart gave full power to consumers in finding, determining and choosing everyday products in accordance with the wishes and needs of consumers.

Technological aspects we can see how the use of Internet technology in the period 2015 - 2016, which we can see in the table below

\section{Compared With Use of Internet Television}


INTERNET USAGE IS VERY CLOSE TO TV Media Landscape in \% (2015-2016)

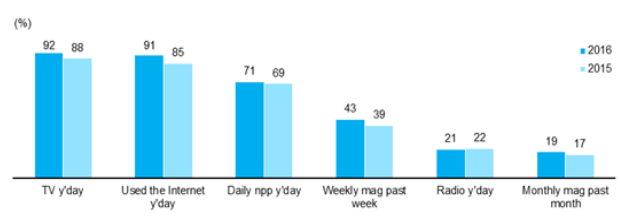

On the bar chart above shows that the use of the internet is growing rapidly from 2015 - 2016. Until this has been a shift in the use of television, radio, newspapers, magazines with the use of the internet, because of the ease of access the internet that helps people obtain the desired information; save time and energy; can play games online and others. While the benefits of watching television only differed from the use of the android program that has many benefits.

\section{Use of the Internet Based on User Age}

\section{LONGER TIME SPENT ON INTERNET (BY AGE BREAK)}

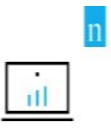

Yesterday internet usage \& Average time spent (mins) per internet user
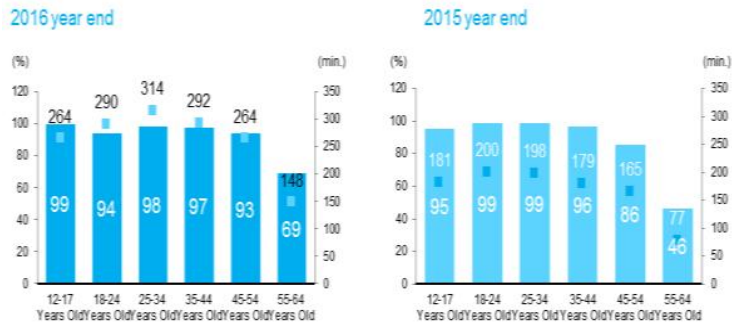

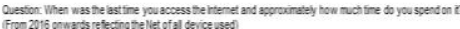

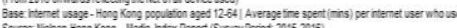

The bar chart above show the number of Internet users aged 12-17 years; The 25-34 and 34-54 years of age is the most widely used internet age. Of the overall bar chart information known to many people who use the Internet in everyday life and it is becoming a business opportunity, especially the retail business. By 2015 Internet users aged 4554 by $86 \%$ and the age of $55-64$ by $46 \%$, in 2016 increased significantly, ie from $86 \%$ to $93 \%$ for ages $45-54$, while from $46 \%$ to $69 \%$ ages $55-64$.

People aged 25-54 can become a major target for retail businesses like OK Mart for teenagers, employees, housewives are assisted in the fulfillment of practical shopping needs, they do not have to bother - bother to go out of the house only to shop, but only with using the internet to buy goods they need. Facility messages between supplied OK Mart, starting from receiving orders from consumers through online or come directly to the store to make online and offline sales strategy is profitable and makes OK Mart can compete and thrive.

Based on the above table it can be concluded that with more and more people using the internet, the more easily we get potential customers.ease of payment and transaction security becomes an important point that must be considered in marketing using the internet. Good after-sales service is also one of the factors that need to be considered, the aim that consumers make purchases back to our store.

\subsection{Aspect Market}

Market Survey is used to assess the business feasibility OK Mart, held between February and March 2017 regarding the factors that influence consumers in shopping at the mini OK Mart. The data used are primary data by distributing questionnaires to 55 respondents were selected using nonprobability sampling with technique purposive sampling

According Rangkuti(2008) Validity is a measure that indicates the level of validity a tool measuring. A valid measuring instrument has validity. Instead of measuring instruments that are less valid means it has a low level of validity. By using LISREL test equipment on the number of respondents 55 people, it can produce $t$ value. Item variables considered valid if the value of $t$ is greater than $t$ table $(2,022)$

\section{Confirmatory Factor Analysis}

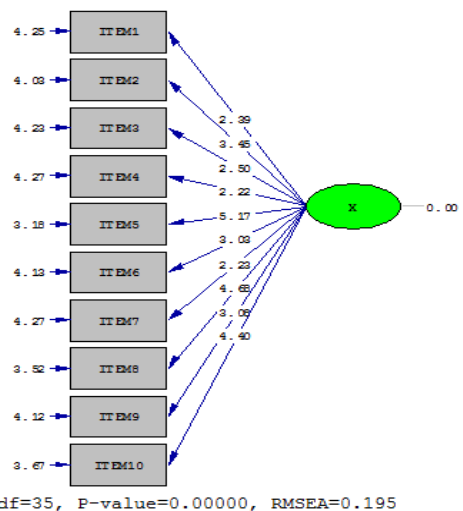

Measurement Equations

ITEM $1=0.248 * \mathrm{X}$, Errorvar $.=0.322, \mathrm{R}^{2}=0.161$
(0.104)
(0.0759)
2.390
4.249

ITEM2 $=0.224 * X$, Errorvar $=0.114, \mathrm{R}^{2}=0.307$

$$
(0.0651) \quad(0.0283)
$$

$3.448 \quad 4.026$

ITEM3 $=0.353 * X$, Errorvar. $=0.592, R^{2}=0.174$

$$
\text { (0.141) (0.140) }
$$

$2.498 \quad 4.231$
ITEM4 $=0.252 * \mathrm{X}$, Errorvar. $=0.388, \mathrm{R}^{2}=0.141$ (0.113) (0.0908)

$2.224 \quad 4.273$

ITEM5 $=0.394 * X$, Errorvar $=0.112, \mathrm{R}^{2}=0.582$ (0.0762) (0.0351)

$5.168 \quad 3.178$

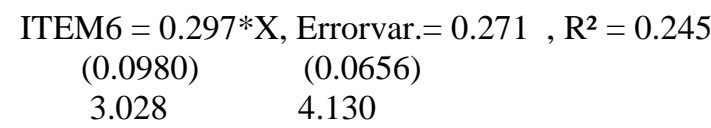
ITEM7 $=0.369 * \mathrm{X}$, Errorvar. $=0.828, \mathrm{R}^{2}=0.141$
(0.166)
(0.194)
2.228
4.272

ITEM8 $=0.486 * \mathrm{X}$, Errorvar. $=0.235 \quad, \mathrm{R}^{2}=$ 0.501

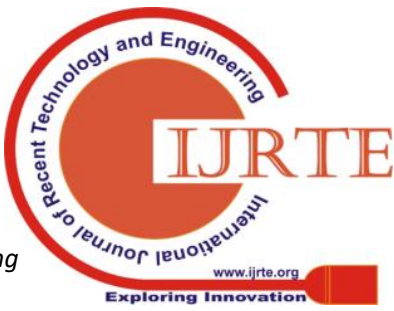



$(0.104)$
$(0.0668)$
4.682
3.520

ITEM9 $=0.403 * X$, Errorvar. $=0.478, \mathrm{R}^{2}=0.253$
$(0.131)$
(0.116)
3.085
4.118

ITEM10 $=0.451 * X$, Errorvar. $=0.243, \mathrm{R}^{2}=0.456$

(0.102) (0.0660)

$$
4.402 \quad 3.672
$$

Table 2. Summary of Hypothesis Results

\begin{tabular}{|c|c|c|c|c|}
\hline No & statement & $\mathrm{t}$ count & t-table & Description \\
\hline 1 & $\begin{array}{l}\text { I shopped ok mart } \\
\text { because of its location } \\
\text { within easy reach of the } \\
\text { home }\end{array}$ & 2,390 & 2,022 & VALID \\
\hline 2 & $\begin{array}{l}\text { I shopped OK Mart } \\
\text { because the products } \\
\text { offered range }\end{array}$ & 3.448 & 2.022 & VALID \\
\hline 3 & $\begin{array}{l}\text { I shopped the OK Mart } \\
\text { because no service } \\
\text { messages between }\end{array}$ & 2,498 & 2,022 & VALID \\
\hline 4 & $\begin{array}{l}\text { I shopped at the OK Mart } \\
\text { for their shopping via } \\
\text { SMS }\end{array}$ & 2,224 & 2,022 & VALID \\
\hline 5 & $\begin{array}{l}\text { I shopped ok mart } \\
\text { because the products } \\
\text { offered completely }\end{array}$ & 5.168 & 2.022 & VALID \\
\hline 6 & $\begin{array}{l}\text { I shopped at the OK Mart } \\
\text { because the products } \\
\text { offered quality good }\end{array}$ & 3.028 & 2.022 & VALID \\
\hline 7 & $\begin{array}{l}\text { I shop at ok mart because } \\
\text { the price offered is ok } \\
\text { mart cheaper than } \\
\text { anywhere else }\end{array}$ & 2,228 & 2,022 & VALID \\
\hline 8 & $\begin{array}{l}\text { I shopped ok mart } \\
\text { because } \\
\text { atmosphere }\end{array}$ & 4.682 & 2.022 & VALID \\
\hline 9 & $\begin{array}{l}\text { Employees serving with } \\
\text { friendly }\end{array}$ & 3.085 & 2.022 & VALID \\
\hline 10 & $\begin{array}{l}\text { I shopped ok mart for } \\
\text { promotion expenditure } \\
\text { attract }\end{array}$ & 4,402 & 2,022 & VALID \\
\hline
\end{tabular}

Umar(2002) in the book Research Methods Business that reliability is a value indicating consistent a gauge in measuring symptoms the same one. Each gauge should have the ability to provide a consistent measurement result.

Reliability Statistics

\begin{tabular}{|r|r|}
\hline $\begin{array}{c}\text { Cronbach's } \\
\text { Alpha }\end{array}$ & N of ltems \\
\hline, 722 & 10 \\
\hline
\end{tabular}

\begin{tabular}{|l|l|l|l|l|}
\hline & $\begin{array}{l}\text { Scale } \\
\text { Mean } \\
\text { Item } \\
\text { Deleted }\end{array}$ & $\begin{array}{l}\text { Scale } \\
\text { Variance } \\
\text { if Item } \\
\text { Deleted }\end{array}$ & $\begin{array}{l}\text { Corrected } \\
\text { Item-Total } \\
\text { Correlation }\end{array}$ & $\begin{array}{l}\text { Cronbach's } \\
\text { Alpha if Item } \\
\text { Deleted }\end{array}$ \\
\hline item_1 & 38.22 & 12.692, & & 332,709 \\
item_2 & 38.85 & 11.645, & & 374,702 \\
item_3 & 38.35 & 11.971, & & 390,699 \\
item_4 & 38.45 & 11.141, & & 428,693 \\
item_5 & 38.62 & 11.018, & & 508,678 \\
item_6 & 38.71 & 11.580, & & 468,687 \\
item_7 & 38.60 & 12.096, & & 469,691 \\
item_8 & 38.44 & 12.102, & 389,700 \\
item_9 & 38.76 & 11.739, & 275,724 \\
item_10 & 38.69 & 12.588, & 251,720 \\
\hline
\end{tabular}

Cronbach's alpha test results on each item show the number more than 0,270 tables of values, therefore it can be concluded that whole grains otherwise reliable for tilapia alpha has approached index 1 (one).

Table 3. Income Statement Projection

OKMart

2017

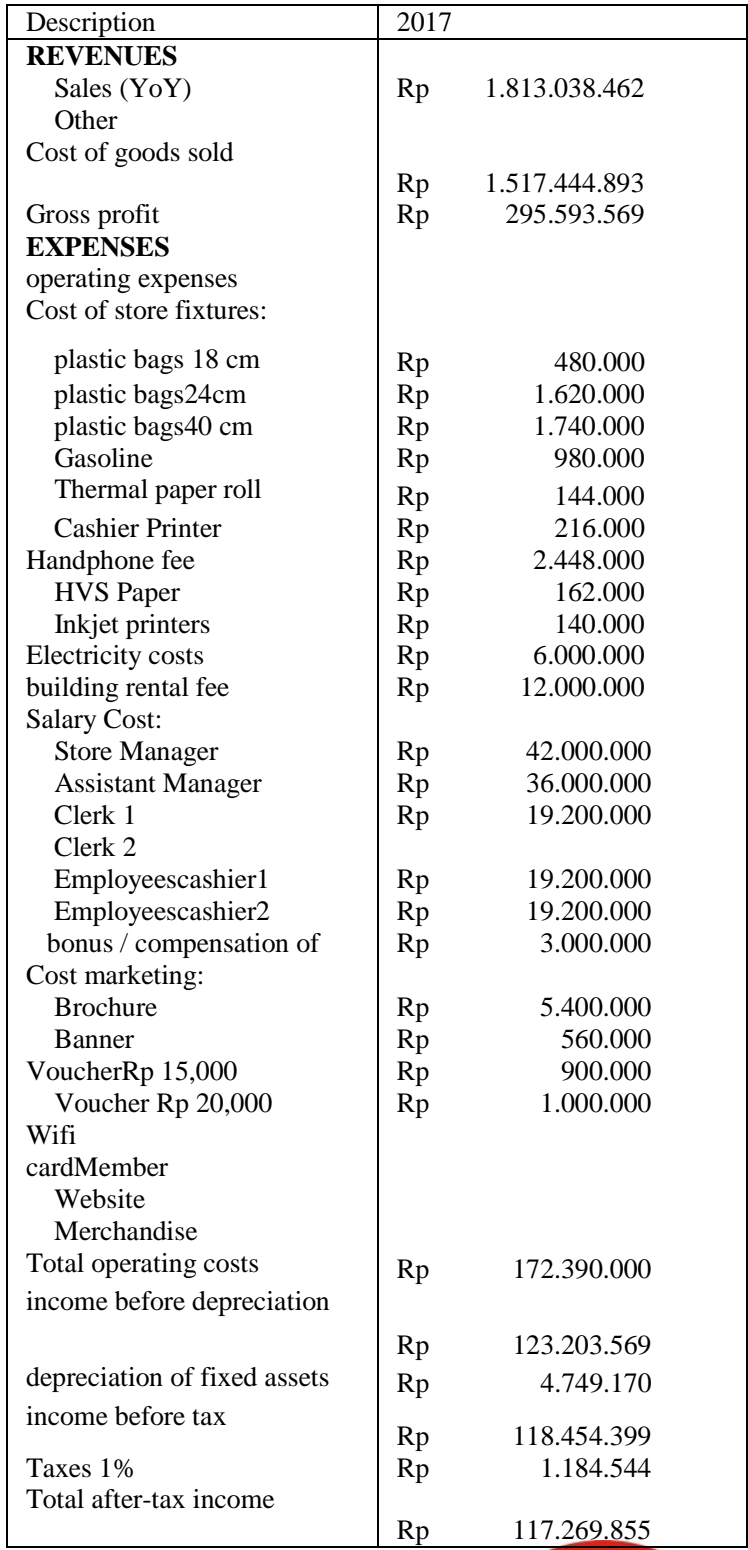

\section{Item-Total Statistics}

Published By: 
OK Mart

2017

\begin{tabular}{|c|c|c|}
\hline Description & \multicolumn{2}{|l|}{2017} \\
\hline \multicolumn{3}{|l|}{ Assets } \\
\hline \multicolumn{3}{|l|}{ Current Assets } \\
\hline \multirow{3}{*}{$\begin{array}{l}\text { Cash } \\
\text { Inventories }\end{array}$} & & \\
\hline & & \\
\hline & $\mathrm{Rp}$ & 15.327 .726 \\
\hline Total current assets & $\mathrm{Rp}$ & 126.355 .284 \\
\hline \multirow{4}{*}{$\begin{array}{l}\text { The fixed assets of } \\
\text { Store equipment } \\
\text { store equipment depreciation } \\
\text { Total assets }\end{array}$} & & \\
\hline & $\mathrm{Rp}$ & 29.213 .357 \\
\hline & $(\mathrm{Rp}$ & 4.749.170) \\
\hline & $\mathrm{Rp}$ & 24.464 .187 \\
\hline Total Assets & $\mathrm{Rp}$ & 150.819 .471 \\
\hline \multicolumn{3}{|l|}{ Liabilities } \\
\hline Tax Payable & $\mathrm{Rp}$ & 1.184 .544 \\
\hline Equity & $\mathrm{Rp}$ & 91.000 .000 \\
\hline Profit & $\mathrm{Rp}$ & 117.269 .855 \\
\hline Prive & $(\mathrm{Rp}$ & $58.634 .927)$ \\
\hline Total Liabilities & $\mathrm{Rp}$ & 150.819 .471 \\
\hline
\end{tabular}

Based on the profit and loss statement and balance sheet OK Mart can be concluded that the ROI, NPV and Payback Period as follows:

\begin{tabular}{|c|c|c|}
\hline ROI (one year) & NPV & Payback period \\
\hline $\begin{array}{l}=\text { Net income } \\
\text { investment value / } \\
\text { value } \\
\text { investments } \\
100 \%\end{array}$ & $\begin{array}{l}\mathrm{NPV}=\mathrm{C} 0+(\mathrm{C} 1 / \\
(1+\mathrm{r}))\end{array}$ & $\begin{array}{lr}= & \text { capital } \\
\text { investment } / & \mathrm{Net} \\
\text { income } & 12 \\
\text { months } & \end{array}$ \\
\hline $28.86 \%=29 \%$ & $\begin{array}{l}\mathrm{Rp} \\
444,806,520.33\end{array}$ & $\begin{array}{l}9.3 \text { months }=9 \\
\text { months } 9 \text { days }\end{array}$ \\
\hline
\end{tabular}

NPV parameters used to assess the feasibility of a Bisnis. Apabila NPV value obtained is greater than 0 , it can be concluded that businesses are eligible to run. Based on the calculation of net income after taxes in the next five years can be generated total NPV of USD 444806 520, which means that the retail business is OK Mart feasible. Calculation of ROI (Return On Investment) for the first year obtained worth $29 \%$, which means that OK Mart to get a return on capital from the sale of $29 \%$ and a turnover of OK Mart will be obtained in the ninth

\section{SWOT OK Mart}

Model SWOT analysis below is used to analyze the strengths (strengths), weaknesses (weaknesses), opportunity (chance), and threats (threats) of the minimarket. Researchers looked at the extent to which the value "PLUS" as the basis of electoral considerations minimarket located in a residential area andhow the condition and situation of the minimarket business.

\begin{tabular}{|l|l|}
\hline Strength & Weakness \\
\hline
\end{tabular}

\begin{tabular}{|c|c|}
\hline $\begin{array}{l}\text { 1. Retail closest to } \\
\text { consumer } \\
\text { 2. Sell staples and diverse } \\
\text { products } \\
\text { 3. There are promotional } \\
\text { strategies to attract both } \\
\text { customers and consumers } \\
\text { 4. Provides convenience in } \\
\text { shopping } \\
\text { 5. Providing practical } \\
\text { convenience for customers in }\end{array}$ & $\begin{array}{l}\text { 1. Human error } \\
\text { in the operations of } \\
2 . \quad \text { Operating } \\
\text { times are fairly short } \\
\text { when compared with } \\
\text { other minimarkets } \\
\text { 3. Store } \\
\text { decoration simple } \\
4 . \quad \text { Salaries below } \\
\text { the minimum wage } \\
5 . \quad \text { Application } \\
\text { systems error for the } \\
\text { sale of goods online }\end{array}$ \\
\hline $\begin{array}{l}\text { Opportunities } \\
\text { 1. Absence shop or provider } \\
\text { of daily needs in Housing } \\
\text { Serua, Depok } \\
\text { 2. Location competitors } \\
\text { quite far from OK Mart } \\
\text { 3. Available message } \\
\text { service } \\
\text { 4. There are some suppliers } \\
\text { who } \\
\text { are partners OK Mart } \\
5 \text {. Many customers move to } \\
\text { OK mart via online because } \\
\text { of the convenience of } \\
\text { shopping }\end{array}$ & $\begin{array}{l}\text { Threat } \\
\text { 1. The presence } \\
\text { of minimarket } \\
\text { franchises scattered in } \\
\text { Depok } \\
2 . \text { Competitor } \\
\text { promotional strategy } \\
\text { every weekend. } \\
\text { 3. The presence } \\
\text { of traditional retailers } \\
\text { such as traditional } \\
\text { merchants, wet market } \\
\text { and a grocery store in } \\
\text { Depok time } \\
\text { 4. The tay in sending goods } \\
\text { delay supplier }\end{array}$ \\
\hline
\end{tabular}

\section{Conclusion}

Based on the calculation of profit in the next five years can be concluded that the NPV (Net Present Value) of Rp 444 806520 which shows that the NPV> 0 meaning that businesses OK Mart feasible (feasible). Values obtained positive ROI OK Mart identifies that a business can receive a sum of money/ income on operations and OK Mart will get a payback on its investment in the ninth month in the first year. Based on the results of SWOT, OK Mart management needs to continuously maintain the existing opportunities and strengths, while the challenge of human error and the salary is below standard UMR regional government regulations.

Step strategy in the field of Human Resources are OK mart employees need to attend training minimarket in order to know the management and procurement of equipment minimarket in the retail business. Necessary also the equalization of salaries wage and the development of the strategic use of online sales is also very important because, with the increase of people who have gone shopping online, it will be a lot of customers who shopped at the OK mart, coupled with the special promo program customers who shop online. Automatic all customers could be regulars from $\mathrm{OK}$ Mart

Profitability on business viability by focusing on aspects financial aspects, market, and marketing aspects, as well as technical and technological aspects, the researchers concluded that the contribution of the most

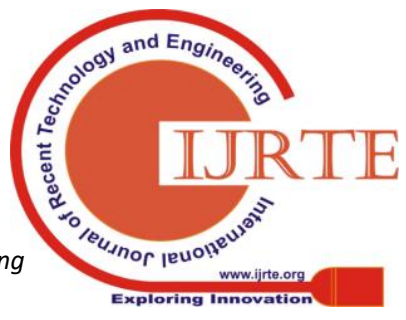


dominant is the facilities the convenience of shopping online, the behavior of consumers shopping in small amounts but often. While from SWOT analysis, researchers concluded that the contribution of the availability of home delivery and minimarket nonfranchised locations are in residential operating time from 7:00 to 22:00 hours, a factor that most contributes to making a profit from the business minimarket.

Ethical clearance - Not required

\section{Source of funding- Self}

\section{Conflict of Interest}

The authors declare no conflict of interest.

\section{References}

[1] Bovee, Courtland L., \& John V Thill. Business Communication Today. (13 ${ }^{\text {th }}$ ed.). New Jersey: Pearson, (2015).

[2] Gambel, Peteraf, Thompson. Essential of Strategic Management: The Quest for Competitive Advantage. ( $4^{\text {th }} \mathrm{ed}$.). New York: McGraw-Hill Education, (2015).

[3] Ghozali, I., \& Fuad. Structural Equation Modeling: LISREL. Semarang: Badan Penerbit Universitas Diponegoro, (2014).

[4] https://chamid29.wordpress.com/2010/07/20/uji-validitas-danreliabilitas-dengan-spss/

[5] http://www.cimbprincipal.com/images/articles/indonesia/Weekly \%20Perspective/2015/May/2015\%2005\%2006\%20CPAM\%20W eekly\%20Indo $\% 20$ Perspective $\% 20$ $\% 20$ Buying\%20The\%20Lifestyle.pdf

[6] Kasali, R. MembidikPasar Indonesia Segmentasi, Targeting, dan Positioning. Jakarta: PT.GramediaPustakaUtama, (2007).

[7] Kotler, P., \& Gary Armstrong. Principles of Marketing. (Global., $14^{\text {th }}$ ed.). United States of America: Pearson Education, (2012).

[8] Kotler, P., \& Keller, K. (2009).Manajemen Pemasaran. (13 $3^{\text {th }}$ ed.). (Penerjemah: Bob Sabran). Jakarta: Erlangga. (Bukuasliditerbitkan 2008)

Margrit, A. (2016). KontribusiEkonomiKreatifMulaiAktif. Diaksestanggal 2 Februari 2017, http://koran.bisnis.com/read/20161209/430/610663/kontribusiekonomi-kreatif-mulai-aktif-

[10] Mulya, Ali Sandy., Effect Generic Strategy and Value-Added Companies Performance on Enterprise Sustainability with Investment Opportunity as Intervening Variable, International Journal of Economic Research, Volume. 14, Number 9, ISSN 0972-9380, (2017).

[11] Mulya, Ali Sandy. The Influence of Value-Added Enterprise, Corporate on Governance on Enterprise Sustainability Companies Performance on Enterprise Sustainability with Investment Opportunity as Intervening Variable, International Journal of Economic Research, Vol. 14, Number 9, ISSN 09729380, (2017).

[12] Nickles, William G., James M. Mchugh\& Susan M. Mchugh. Understanding Business. (International ed.). New York: McGraw Hill Education, (2016).

[13] PetaBisnisRitel Modern di Indonesia Tangerang: Bisnis Information Focus, 2016 - 2020.

[14] Pheng, Sui Low. Marketing theories and concepts for the International Construction Industry: A Study of Their Applicability at the Global, National, and Corporate Perspectives, A Thesis Presented to the University of London as part of the Requirements for the Award of the degree of Doctor of Philosophy, ( 1990).

Principal, CIMB. Buying The Lifestyle, (2015).

[16] Rangkuti, F. The Power of Brand“" TeknikMengelola Brand Equity danStrategiPengembanganMerek Plus

AnalisisKasusdengan SPSS. Jakarta: GramediaPustakaUtama, (2008).

[17] Rangkuti, F. Analisis SWOT TeknikMembedahKasusBisnis. Jakarta: PT GramediaPustakaUmum, (2009).

[18] Rangkuti, F., Analisis SWOT: TeknikMembedahKasusBisnis, Jakarta: PT GramediaPustakaUtama, (2006).

Gate, England: Pearson Education Prentice Hall, (2016).

Asep ST. Manajemen Minimarket. Jakarta: RaihAsaSukses (PenebarSwadaya Group), (2013).

$R$ ised Riset Bisnis Pandua Mahasiswauntuk Melak iset Dileng kapi Contoh Proposal dan Hasil Riset Aanajemendan Akuntansi. Jakarta: Gramedia Pustaka Utama, (2002). 